\title{
The Impact Of Dividend Payments On Shareholders' Wealth: Evidence From The Vector Error Correction Model
}

Johannes de Wet, University of Pretoria, South Africa

Mvita Mpinda, University of Pretoria, South Africa

\begin{abstract}
To date, a vast body of research has been established on dividend policy. However, little research has been done on the impact of dividend payments on shareholders' wealth while considering the short- and long-run effects. This study is based on a sample of 46 companies listed on the Johannesburg Securities Exchange (JSE) for the period 1995 to 2010. The Vector Error Correction Model (VECM) was used to describe the short-run and long-run dynamics or the adjustment of the co-integrated variables toward their equilibrium values. Results indicate that in the long run, dividend yield is positively related to market price per share, while earnings per share do not have a significant impact on the market price per share.
\end{abstract}

Keywords: Dividend Payments; Market Price per Share; Earnings per Share; Shareholders' Wealth; Relevance and Irrelevance Theory; Vector Error Correction Model; Granger Causality Model; Johansson Co-Integration Test

\section{INTRODUCTION}

\section{Background}

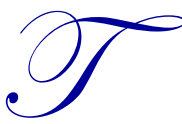

he principal financial objective of a business enterprise is to maximise the wealth of its shareholders (Rappaport, 1998:1). This corporate function of maximising shareholders' wealth assumes that managers operate in the best interests of stockholders (Priya \& Azhagaiah, 2008:186). This takes place when the returns of the shareholders, relative to the investment, are maximised. In addition, these returns are made up of capital gains in the form of increases in the share prices, as well as dividends, which are made possible when the company generates adequate distributable profits.

According to Priya and Azhagaiah (2008:181), shareholders' wealth is represented in the market price of the company's common stock, which, in turn, is a function of the company's investment, financing and dividend decisions. The primary goal of maximising shareholders' wealth translates into maximising the value of the company, which is measured by the price of the company's common stock (Priya \& Azhagaiah, 2008:181-182). It should be borne in mind that although shareholders like cash dividends, they prefer growth in the earnings per share (EPS), which results from ploughing earnings back into the business.

The modern approach of financial management provides a conceptual and analytical framework for decision-making which emphasises the effective use of resources in order to create shareholders' wealth. Consequently, the market value of the ordinary shares of a corporation is seen as the main indicator of shareholders' wealth. The optimal dividend policy is one that maximises the company's stock price; this leads to maximisation of shareholders' wealth and thereby ensures rapid economic growth (Priya \& Azhagaiah, 2008:182).

When facing uncertainty, it is not always easy for a company to achieve its objectives. Wealth creation in an entrepreneurial and established organisation is a complex and challenging task (Rowe, 1993:81). In an everchanging environment, any organisation wishing to maintain a competitive position and satisfy its shareholders 
should be engaging in planning every time there is a need to do so. The essence of good management includes the ability to plan. According to Kenyon and Mathur (2001), business strategy is receiving more and more attention because competition is becoming more intense.

Goodstein, Nolan, and Pfeiffer (1993:1) suggest that to be successful and create wealth, a strategic planning process should provide the criteria for making day-to-day decisions and should provide a template against which all such decisions should be evaluated. Varaiya, Kerin and Weeks (1987) put it simply by saying that interest in shareholders' wealth creation is increasing in practice. Sutton (1983:153) asserts that it is meaningless to ask whether a strategy pays; the reason for this is that all organisations follow a strategy of some sort, however informal it may be. The utility value of dividends differs widely among shareholders; for instance, investors with a long-term perspective are adamant that a dividend should only be paid if the company has no other value-enhancing capital projects to invest in.

\section{Problem Statement}

Over 50 years ago, Lintner (1956) published a study of corporate dividend policy in which he found that firms typically set long-term target dividend payout ratios. He also found that dividend changes tend to lag behind earnings changes in order to give management time to assess the performance of any rises in earnings which could exert a positive impact on shareholders' wealth.

Several other studies were conducted using different approaches regarding dividend policy and shareholders' wealth. Miller and Modigliani (1961) demonstrated that in perfect, frictionless markets, investors should be indifferent to whether they receive their returns in the form of dividends or in the form of price appreciation. In South Africa, Ooms, Archer and Smit (1987), Knight and Affleck-Graves (1987), Botha, Bosch and Van Zyl (1987), Auret and De Villiers (2000), and Clarke (2007) found substantive information signals about the size of future earnings within dividend announcements.

In South Africa, few studies have analysed the relationship between shareholders' wealth and dividend payment using an error correction model and multiple regression methods.

Net earnings are divided into two parts: retained earnings and dividends. The retained earnings may be reinvested and treated as a source of long-term funds. However, the dividends should be distributed to shareholders in order to maximise the shareholders' wealth, as the shareholders have invested their money with the expectation of benefitting financially. Therefore, the present study analyses to what extent the level of dividend payout affects the shareholders' wealth, particularly for companies registered on the Johannesburg Securities Exchange (JSE).

With regard to the multiple regressions method, the Priya and Azhagaiah (2008) equations and methodology are used for the purposes of this study. With regard to the error correction model, the Ghosh, Coyne and Boldin (2004) approach is used.

\section{Purpose of Study}

The main purpose of this study is to examine how South African companies listed on the JSE create wealth for their shareholders by analysing how far the level of dividend payout affects the shareholders' wealth using an error correction model approach and multiple regression methods.

\section{Research Objectives}

The following specific objectives guide the study:

- to provide ways of analysing and evaluating the companies' abilities to create wealth for their shareholders, using an error correction model and multiple regression methods

- to analyse the impact of variations in dividend policy on shareholders' wealth in dividend-paying and nondividend-paying companies listed on the JSE 
- $\quad$ to analyse the impact of earnings per share and past performance in the presence of dividend policy on shareholders' wealth

- $\quad$ to identify whether current dividend policies are enhancing shareholders' wealth

\section{Importance and Benefits of the Study}

In the ever-growing South African economy, globalisation and privatisation, together with rapid changes in information technology, whereby the customer has been empowered, have brought intense competition in every field of activity. In order to maintain competitive positions and add value to their companies, today's financial managers need to make critical business and financial decisions which lead to the long-run maximisation of the shareholders' wealth.

The study will hopefully make a contribution toward the academic literature on the link between dividend policy and shareholder wealth creation and encompasses investigating South African companies on the JSE, using a vector error correction model and multiple regression methods.

\section{Delimitations}

While it is acknowledged that it is common practice to distribute funds to shareholders in a number of different ways, which include ordinary annual dividend payments, special dividends and share buybacks, this study focuses exclusively on the normal total annual dividend payments of companies. The study is limited to the South African context and only data from companies listed on the JSE are used. The study focuses on companies listed on the JSE because data for these companies are easily obtained from various sources. In contrast, it is difficult to obtain adequate data for unlisted companies. The data were sourced from the McGregor Bureau of Financial Analysis (BFA) website.

\section{Assumptions}

An assumption is a condition that is taken for granted, without which the research project would be pointless (Leedy \& Ormorod, 2005:5). Several basic assumptions underlie the current research study. As such, it is assumed that:

- $\quad$ All organizations are involved in the creation of shareholders' wealth.

- Shareholders' wealth is a recognisable phenomenon within an organization.

- The creation of wealth varies, depending on the kind of organisation and the cost of capital involved.

- $\quad$ The three variables; namely, dividend per share, earnings per share and market price per share, are nonstationary.

- $\quad$ There is a long-run equilibrium between the dividend per share and the market price per share.

\section{LITERATURE REVIEW}

\section{Dividend Policy}

Dividend policy has been the subject of considerable debate since Miller and Modigliani (1961) illustrated that under certain assumptions, dividends were irrelevant and had no influence on a firm's share value. Since then, financial researchers and practitioners have disagreed with Miller and Modigliani's proposition and have argued that they based their proposition on perfect capital market assumptions, assumptions that do not hold in the real world.

While determining dividend policy, the management of a company must consider to what extent the dividend policy would influence firm value because the objective of financial management is the maximisation of shareholders' wealth. This objective can be achieved by giving the shareholders a 'fair' payment on their investment. The payment of a dividend should be preferred if it will lead to the maximisation of the owners' wealth. If it will not do so, the firm should retain the profit and should not distribute dividends. The payout decisions a financial manager has to take refer to the choice between paying dividends and repurchasing shares. However, the impact of a firm's 
dividend policy on its shareholders' wealth is still unresolved. Dividend policy is one of the most widely researched topics in finance. Yet, researchers have different views about whether the percentage of earnings that a firm pays out in dividends materially affects the firm's long-term share price.

\section{Irrelevance of Dividends}

The main proponents of this view are Miller and Modigliani (1961). According to their theory and based on certain strict assumptions, the dividend decision does not affect the value of the firm and is therefore of no consequence. It is the investment policy and earning power of the assets of the firm, and not the capital structure, that affects the value of the firm. They argue that if a dividend is paid, the company will have to raise the capital of the same amount as the dividend at a later stage. There will then be more issued shares for the same assets and therefore the value of the existing shares will be diluted by the amount of dividends (Correia, Flynn, Uliana \& Wormald, 2006:14-16). It is immaterial whether the company pays a dividend out of its earnings or retains the earnings in the business. Miller and Modigliani argue that the value of the firm depends on the firm's earnings, which result from its investment policy. Hence companies should invest excess funds in positive net present value projects instead of paying them out to shareholders. 2002:756):

Modigliani and Miller's hypothesis of irrelevance is based on the following assumptions (Pandey,

- $\quad$ The firm operates in a perfect capital market where investors behave rationally, information is freely available to all, and transaction and flotation costs do not exist. Perfect capital markets also imply that no investor is large enough to affect the market price of shares.

- $\quad$ Taxes do not exist or there is no difference in the tax rate applicable to capital gains and dividends. This means that investors value a dollar of dividend as much as a dollar of capital gain.

- $\quad$ The firm has a fixed investment policy.

- $\quad$ Risk of uncertainty does not exist.

\section{Relevance of Dividends}

This school of thought considers dividends to be active variables, affecting the value of the firm. The view is supported by Lintner (1956), Gordon (1959) and Walter (1963) According to them, the dividend policy almost always affects the value of the enterprise, and the investment policy of a firm cannot be separated from its dividend policy. These authors introduced competing theories and hypotheses to provide empirical evidence to prove that when the capital market is imperfect, dividends exert an impact on share value. Consequently, according to the "bird in the hand' theory of Miller and Modigliani, investors prefer dividends (which are certain) to retained earnings (which are less certain). The intuitive deduction is that firms should set a large dividend payout ratio to maximise firm share value (Brigham and Gordon, 1968; Lintner, 1956; Gordon, 1959; Fisher, 1961; Walter, 1963).

The dividend relevance theory relaxes the assumption of perfect capital markets and rational investors. It analyses empirically the behaviour patterns of dividend distributions and their effect on the value of the firm. In the real world, market frictions are not costless and investors do not always act rationally (Lease, John, Kalay, Loewenstein \& Sarig, 2000:45). The dividend relevance theory is also seen as a reaction to the dividend irrelevance theory which stated that under conditions of certainty and uncertainty, changes in dividend policy do not affect firm value. Botha (1985:55) defines dividend policy under the relevance theory as, "The dividend policy is a practical approach which treats dividends as an active decision variable and retained earnings as the residue; dividends are more than just a means of distributing net profit, and any variation in dividend payout ratio could affect shareholders' wealth; a firm should therefore endeavor to establish an optimal policy that will maximize shareholders' wealth."

According to Maditinos, Sevic, Theriou and Tsinani (2007:21), companies that pay healthy dividends are often thought to be relatively honest and reliable and less influenced by accounting manipulations. Healthy dividends are an indication that the company generates real earnings that are being grown over a long period of time. Dividends remove uncertainty about the level of earnings. Therefore, a higher dividend raises the price of shares. 
Tibrewala, Biger and Gill (2010:10) found that the view of a dividend payout ratio on an adjusted basis; namely, the ratio between the cash dividend and the net cash flow generated by the firm, gave rise to results that are different from those obtained with the usual dividend payout ratio as the dependent variable. The following variables were used: sales growth, corporate profitability, market-to-book value, tax and cash flow. It should be noted that the dividend policy was not among the variables used.

Studies based on data collected during times of relatively higher inflation found that many companies paid dividends in excess of their real earnings (Du Plessis, Archer \& Affleck Graves, 1986; and Gevers \& Hamman, 1988). These findings suggest that at least maintaining the current nominal dividend is an important factor in dividend policy. Auret and De Villiers (2000), using a multiple linear regression technique, found that the earnings per share (EPS) had greater explanatory power than the dividend per share (DPS) in the explanation of share prices.

Nel, Hamman and Smit (in Maytham, Gilbert \& Firer, 2008:7) investigated whether changes in dividends contain information about future and/or present changes in earnings. They studied 278 JSE-listed companies and found no evidence that future increases in earnings are predicted by dividend changes, but rather found that these changes are the response to changes in the current and past earnings. They found that management is reluctant to increase or decrease dividends since a decrease sends a negative signal and an increase will only occur if the managers are confident that the current level of earnings will be maintained in the future. Clarke (2007) found that small share repurchases generally signal large abnormal earnings growth, but that large purchases offer no such signal.

\section{RESEARCH METHODOLOGY USING PANEL DATA APPROACH}

A panel data approach was used to measure the relationship between the dividend policy and the stock prices. The results of the study were based on the fixed-effect model, as it provides statistically better results than the pooled ordinary least squares (OLS) and random-effect models when characteristics of the sample differ. The fixed-effect method was used to control all the stable characteristics of the companies included in the study over a fixed period of time. As mentioned before, this method provides statistically better results by removing the bias from the data and explains only within-sample variations. It should be noted that the random effect method was applied when characteristics of the sample differed.

All the companies differed with regard to factors such as size, assets, number of shareholders, management and leverage. That is why the random effect model was used. This method is suitable for explaining variations between companies. The same approach was adopted by Pani (2008), Rashid and Rahman (2009), Nazir, Nawaz, Anwar and Ahmed (2010), Hussainey, Mgbame and Chijoke-Mgbame (2011), and Kahn, Aamir, Qayyum, Nasir and Kahn (2011) in their studies. The basic test entailed finding the correlation between the dependent variable, market price per share, against the dividend per share. The fixed-effect model was used to determine the effect of dividends on the market price per share. It was expected that all the dividends per share and earnings per share would be positively associated with the market price per share.

\section{ANALYSIS AND RESULTS}

Estimating a model that includes time series variables requires making sure that all the time series variables in the model are either stationary or co-integrated, which means that they are integrated of the same order and errors are stationary. In that case, the model defines a long-run equilibrium relationship between the co-integrated variables. Therefore, a co-integration test was done in two stages. The first stage entailed conducting a unit root test on each variable to find the order of integration. If all the variables were integrated of the same order, the second stage entailed estimating the model, also called the co-integrating equation, and testing whether the residual of the model was stationary. For the purposes of this study, there were three variables to be tested - the market price per share, the dividend per share, and the earnings per share.

Before calculating the panel unit root test, descriptive statistics need to be presented. Table 1 shows the details of the descriptive statistics that affected the market price per share of 46 companies during the period 1995 2010. 
Table 1: Descriptive Statistics

\begin{tabular}{|l|c|c|c|c|}
\hline \multicolumn{1}{|c|}{ Variables } & Minimum & Maximum & Mean & Standard Deviation \\
\hline Market Price Per Share & 1.05 & $110,551.00$ & $5,279.15$ & $9,619.75$ \\
\hline Dividend Per Share & 1.50 & $8,700.00$ & 226.75 & 541.34 \\
\hline Earnings Per Share & $-1,880.00$ & $13,772.00$ & 472.48 & $1,002.79$ \\
\hline
\end{tabular}

The market price per share (in cents), which was the dependent variable, ranged from 1.05 to $110,551.00$, with a mean value of 5,279.15 and a standard deviation of 9,619.75. For the first model, there was one explanatory variable - the dividend per share. The dividend per share (in cents) ranged from 1.50 to 8700.00 , having a mean value 226.75 and a standard deviation of 541.34. For the second model, earnings per share were included. The earnings per share (in cents), which was the second explanatory variable, ranged from -1,880.00 to 13,772.00, with a mean of 472.48 and a standard deviation of 10,002.79.

\section{PANEL UNIT ROOT TEST}

Non-stationary (trended) time series data can potentially be a major problem for empirical econometrics. It is well known that trends, either stochastic or deterministic, may cause spurious regressions, uninterrupted student-t values and other statistics, as well as goodness of fit measures which are too high and, as a rule, trends make regression results rather difficult to evaluate. However, most macro-economic time series are subject to some type of trend. Some researchers have suggested a remedy; namely, to difference a series successively until a stationary state is achieved. Nevertheless, it has been proven that differencing results in a loss of some valuable long-run information in the data.

A real breakthrough in time-series econometrics came in the early 1980s with the concept of co-integration. Co-integration analysis allows non-stationary data to be used so that spurious results are avoided. It also provides applied econometricians with an effective formal framework for testing and estimating long-run models from actual time series data. The market price per share, dividend per share, and earnings per share are usually non-stationary. If the traditional OLS method is used, it may produce the spurious regression problems mentioned by Granger and Newbold (1974) and may lead to statistical bias. Consequently, the study first examined whether the data were stationary.

It is well known that the traditional unit root method (ADF test, PP test, and Ng-Perron test) involves a low test power problem because of insufficient data. Panel data could increase the number of observations and the time period; hence, it could improve the power of the test. In the unit root test of levels, the researcher included an intercept and also a time trend if data were trended. In the unit root of the first differences, only the intercept was included without the time trend.

\section{Unit Root Test for the Market Price per Share}

Table 2 provides the results for the unit root test of the market price per share to determine if the market price per share is non-stationary or stationary.

Table 2: Market Price per Share Unit Root Test

\begin{tabular}{|c|c|c|}
\hline \multicolumn{3}{|c|}{ In Levels Market Price per Share(MPS) Only Intercept } \\
\hline & Statistic & Prob. \\
\hline ADF-Fisher Chi-square & 50.99 & 0.99 \\
\hline PP-Fisher Chi-square & 73.57 & 0.92 \\
\hline \multicolumn{3}{|c|}{ In Levels Log Market Price per Share(LMPS) Only Intercept } \\
\hline & Statistic & Prob. \\
\hline ADF-Fisher Chi-square & 61.11 & 0.99 \\
\hline PP-Fisher Chi-square & 121.42 & 0.02 \\
\hline \multicolumn{3}{|c|}{ In Levels Differenced Log Market Price per Share(D(L DP) Only Intercept } \\
\hline & Statistic & Prob \\
\hline ADF-Fisher Chi-square & 220.80 & $0.00^{* * * * *+1}$ \\
\hline PP-Fisher Chi-square & 494.01 & $0.00^{* * \cdots \times}$ \\
\hline
\end{tabular}

Notes: $10 \%, 5 \%, 1 \%$ indicated by ${ }^{* * *},{ }^{* * *}$, respectively.

1456 Copyright by author(s) $\underline{\text { Creative Commons License CC-BY }}$ 


\section{Unit Root Test for the Dividend per Share}

Table 3 provides the results for the unit root test of the dividend per share to determine if the dividend per share is stationary or non-stationary.

Table 3: Dividend per Share Unit Root Test

\begin{tabular}{|l|c|c|}
\hline In Levels Dividend per Share(DP) Only Intercept & Statistic & Prob. \\
\hline ADF-Fisher Chi-square & 67.42 & 0.97 \\
\hline PP-Fisher Chi-square & 95.28 & 0.39 \\
\hline In Levels Log Dividend per(L DP) Only Intercept & Statistic & Prob. \\
\hline \multicolumn{2}{|c|}{0.99} \\
\hline ADF-Fisher Chi-square & 58.13 & 0.85 \\
\hline PP-Fisher Chi-square & 78.30 & Prob. \\
\hline In Levels Differenced Log Dividend per Share(L DP) Only Intercept & Statistic & $0.00^{* * * * *}$ \\
\hline \multicolumn{2}{|c|}{238.58} & $0.00^{* * * * *}$ \\
\hline ADF-Fisher Chi-square & 447.72 & \\
\hline PP-Fisher Chi-square & & \\
\hline
\end{tabular}

\section{Unit Root Test for the Earnings per Share}

Table 4 provides the results for the unit root test of the earnings per share to determine if the earnings per share are stationary or non-stationary.

Table 4: Earnings per Share Unit Root Test

\begin{tabular}{|c|c|c|}
\hline \multicolumn{3}{|c|}{ In Levels Earnings per Share(EP) Only Intercept } \\
\hline & Statistic & Prob. \\
\hline ADF-Fisher Chi-square & 58.28 & 0.99 \\
\hline PP-Fisher Chi-square & 68.24 & 0.97 \\
\hline \multicolumn{3}{|c|}{ In Levels Log Earnings per Share(LEP) Only Intercept } \\
\hline & Statistic & Prob. \\
\hline ADF-Fisher Chi-square & 54.60 & 0.99 \\
\hline PP-Fisher Chi-square & 66.43 & 0.98 \\
\hline \multicolumn{3}{|c|}{ In Levels Differenced Log Earnings per Share D(LEP) } \\
\hline & Statistic & Prob. \\
\hline ADF-Fisher Chi-square & 209.39 & $0.00^{* * * 2}$ \\
\hline PP-Fisher Chi-Square & 377.79 & $0.00^{* * * 2}$ \\
\hline
\end{tabular}

In using the market price per share, dividend per share, and earnings per share, the probability of results suggested that the three variables were not stationary. Logs were introduced in the study to determine if there might be a change, but still the variables were non-stationary. Looking at the probability, MPS, DP and EP were stationary of order I (1). The three variables were of the same order. The model defined a long-run equilibrium relationship between the co-integrated variables. Therefore, a co-integration test was done. 


\section{THE VAR LAG ORDER SELECTION CRITERIA}

In order to obtain the optimal lag length for co-integration analysis, the var lag order of integration is performed. Table 5 shows the lag order selection statistics that indicate lag order at 8 , so the analysis is continued with lag 8.

Table 5: The VAR Lag Order Selection Criteria

\begin{tabular}{|l|c|c|c|c|c|}
\hline Lag & LogL & LR & AIC & SC & HQ \\
\hline 0 & -9932.94 & NA & 54.00 & 54.03 & 54.01 \\
\hline 1 & -9525.39 & 806.24 & 51.83 & 51.96 & 51.88 \\
\hline 2 & -9464.57 & 119.32 & 51.55 & 51.78 & 51.64 \\
\hline 3 & -9442.03 & 43.87 & 51.48 & 51.80 & 51.60 \\
\hline 4 & -9432.30 & 18.76 & 51.47 & 51.89 & 51.64 \\
\hline 5 & -9373.09 & 113.27 & 51.20 & 51.71 & 51.40 \\
\hline 6 & -9190.35 & 346.61 & 50.26 & $50.86^{*}$ & 50.50 \\
\hline 7 & -9171.65 & 35.18 & 50.20 & 50.91 & $50.48^{*}$ \\
\hline 8 & -9156.54 & $28.16^{*}$ & $50.17^{*}$ & 50.97 & 50.49 \\
\hline
\end{tabular}

\section{The Johansen Co-Integration Test and the VEC Granger Causality Test}

The Johansen co-integration test sets out the long run relationship between the market price per share, dividend per share, and earnings per share. Table 6 contains the results of the test.

Table 6: Results of Johansen Co-Integration Test

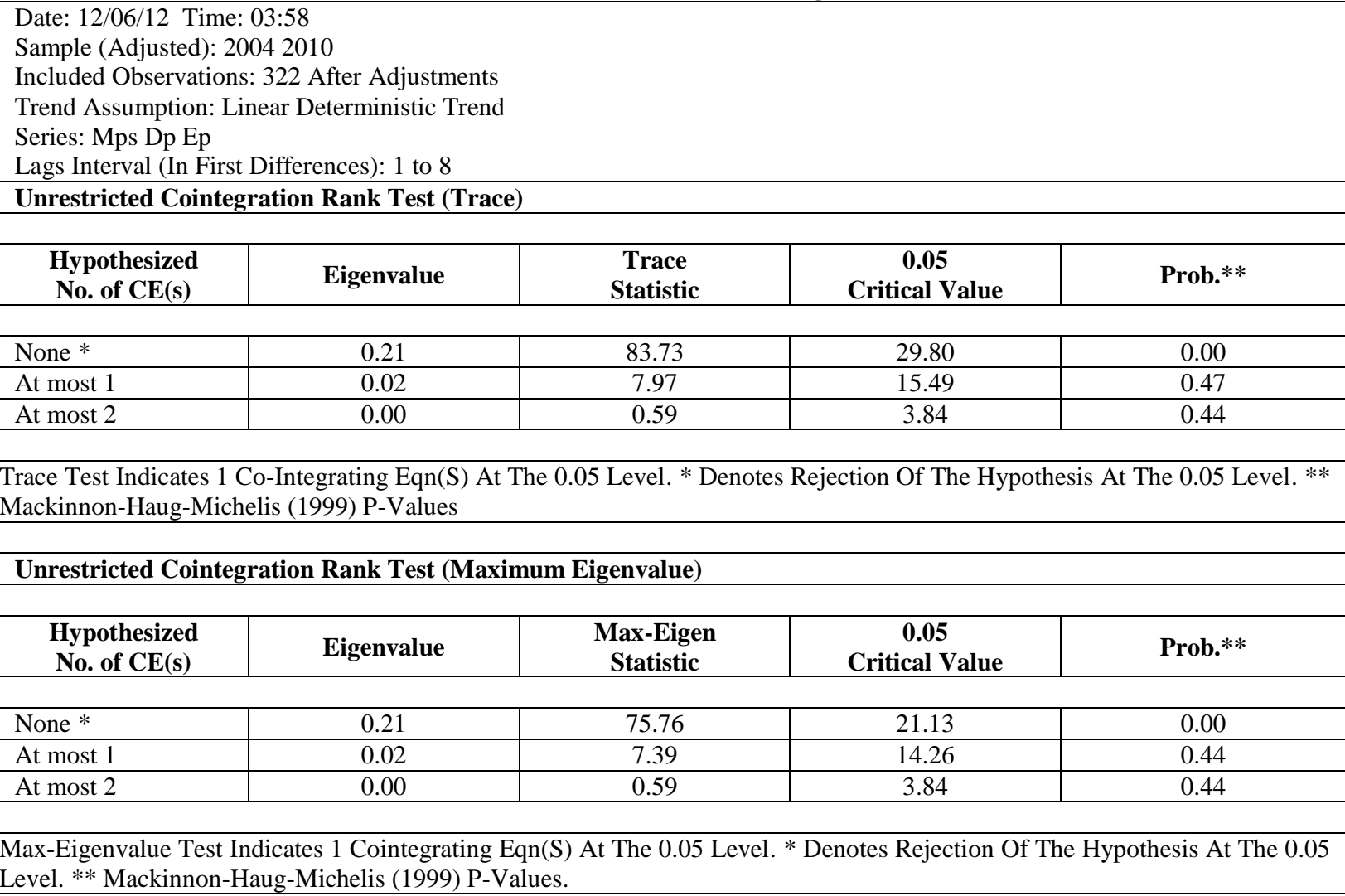

The statistical results underline what most statisticians noted before on economic series which are highly trended with stationary growth rates. It should be noted that because they are integrated, there is an error correction scenario. 
Table 7 reflects the results of the VEC Granger causality tests.

Table 7: The VEC Granger Causality Test

\begin{tabular}{|c|c|c|c|}
\hline $\begin{array}{l}\text { VEC Granger Causalit } \\
\text { Sample: } 19952010 \\
\text { Included Observations: }\end{array}$ & $\begin{array}{l}\text { y/Block Exogeneity Wald Tests } \\
322\end{array}$ & & \\
\hline Dependent Variable: & D(LMPS) & & \\
\hline Excluded & Chi-sq & df & Prob. \\
\hline $\mathrm{D}(\mathrm{LDP})$ & 18.50 & 8 & $0.02^{* * *}$ \\
\hline $\mathrm{D}$ (LEP) & 11.21 & 8 & 0.19 \\
\hline All & 28.96 & 16 & 0.02 \\
\hline Dependent Variable: & D(LDP) & & \\
\hline Excluded & Chi-sq & df & Prob. \\
\hline D(LMPS) & 27.07 & 8 & $0.00^{* * * * 2}$ \\
\hline $\mathrm{D}(\mathrm{LEP})$ & 14.20 & 8 & 0.08 \\
\hline All & 41.76 & 16 & 0.00 \\
\hline Dependent Variable: & D(LEP) & & \\
\hline Excluded & Chi-sq & df & Prob. \\
\hline D(LMPS) & 6.29 & 8 & 0.62 \\
\hline $\mathrm{D}(\mathrm{LDP})$ & 7.49 & 8 & 0.48 \\
\hline All & 14.00 & 16 & 0.60 \\
\hline
\end{tabular}

Notes: ${ }^{* * * * * *}$ denotes the level of significance at $10 \%, 5 \%$, and $1 \%$.

The results validate the finding of the long-run relations among market price per share, dividend per share, and earnings per share. The market price per share was affected by the dividend per share, while the earning per share did not Granger-cause the market price per share. The market price per share Granger-caused the dividend per share. This indicates that there is a bi-directional Granger causality between the market price per share and the dividend per share of South African companies.

\section{THE FIXED EFFECT MODEL AND THE RANDOM EFFECT MODEL}

Fixed and Random Effect models were also applied to the panel data to validate the results. The Fixed Effects method was used to control all the stable characteristics of the companies included in the study over a fixed period of time. This method provides statistically better results by removing the bias from the data and explains only within-sample variations. The Random Effect method was applied when characteristics of the sample differed. As the characteristics of companies are different in terms of size, amount of capital, number of shareholders, nature of business, and earnings, the Random Effect method is suitable for explaining variations between the dividend payments and the market price per share. These methods were also adopted by Pani (2008), Rashid and Rahman (2009), Nazir, Nawaz, Anwar and Ahmed (2010), and Hussainey, Mgbame and Chioke-Mgbame (2011) in their studies.

\section{Fixed Effect Model}

Table 8 shows the correlation between the market price per share and the dividend per share. The market price per share was the dependent variable and the correlation was tested at a $5 \%$ level of significance, using the fixed effect model. 
Table 8: Fixed Effect Model 1

\begin{tabular}{|l|c|c|c|c|}
\hline \multicolumn{5}{|c|}{ Panel Least Squares Method } \\
\hline Dependent Variable LMPS & Std. Error & t-statistic & Prob. $^{* * * *}$ \\
\hline \multicolumn{1}{|c|}{ Variables } & Coefficient & 0.38 & 14.62 & 0.0000 \\
\hline C & 5.53 & 0.084 & 5.28 & 0.0000 \\
\hline LDP & 0.44 & Adjusted R-squared & 0.80 & \\
\hline Effect Specification & \multicolumn{5}{|c|}{} \\
\hline R-squared & 0.81 & Prob & 0.00 & \\
\hline F-statistic & 65.76 &
\end{tabular}

Notes: ${ }^{* * *}$ denotes the significance at $1 \%$. The P-value for dividend per share indicates that it is significant in exerting a positive impact on the market price per share. The regression accounts for $81 \%$ of the variance in the dependent variable. The $19 \%$ percent is explained by other variables.

In the second model, using the same approach, the earnings per share was included as the third variable. The results are presented in Table 9.

Table 9: Fixed Effect Model 2

\begin{tabular}{|l|c|c|c|c|}
\hline \multicolumn{5}{|c|}{ Panel Least Squares Method } \\
\hline Dependent Variable LMPS & Std. Error & t-statistic & Prob. \\
\hline \multicolumn{1}{|c|}{ Variables } & Coefficient & 1.21 & 2.89 & 0.00 \\
\hline C & 3.48 & 0.06 & 6.65 & $0.00^{* * * * *}$ \\
\hline LDP & 0.42 & 0.17 & 1.66 & 0.10 \\
\hline LEPS & 0.28 & \multicolumn{5}{l|}{} \\
\hline Effect Specification & 0.82 & Adjusted R- squared & 0.80 & \\
\hline R- squared & 64.75 & Prob(F-statistic) & 0.00 & \\
\hline F-statistic &
\end{tabular}

The P-value for dividend per share indicates that it is significant in exerting a positive impact on the market price per share. The regression accounts for $82 \%$ of the variance in the dependent variable.

From Table 10, it is clear that the dividend per share is significant in explaining the changes in the market price per share. The model accounts for $82 \%$ of the variance in the dependent variable (MPS). The p-value (0.0971) for earnings per share shows that it is weakly insignificant in explaining the variations in the market price per share.

\section{Random Effect Model}

Because the 46 companies have different characteristics and differ in terms of their size, assets, number of shareholders, management and leverage, the random effect model needed to be considered, as it explains variations between enterprises. Table 10 indicates the results obtained:

Table 10: Random Effect Model 1

\begin{tabular}{|l|c|c|c|c|}
\hline \multicolumn{5}{|l|}{ Dependent Variable LMPS } \\
\hline \multicolumn{1}{|c|}{ Variables } & Coefficient & Std.Error & t-statistic & Prob. $^{* * * *}$ \\
\hline C & 5.54 & 0.58 & 9.49 & 0.00 \\
\hline LDP & 0.44 & 0.06 & 7.33 & 0.00 \\
\hline Effect Specification & \multicolumn{5}{|l|}{} \\
\hline R-squared & 0.21 & Adjusted R-squared & 0.21 & \\
\hline F-statistic & 195.06 & Prob & 0.00 & \\
\hline
\end{tabular}

Using the random effect model, the dividend per share is still significant, although the model accounts for only $21 \%$ of the variance in the market price per share. 
Table 11 shows the results when introducing the earnings per share under the random effect model.

Table 11: Random Effect Model 2 - Panel Least Squares Method

\begin{tabular}{|l|c|c|c|c|}
\hline \multicolumn{5}{|l|}{ Dependent Variable LMPS } \\
\hline \multicolumn{1}{|c|}{ Variables } & Coefficient & Std.Error & t-statistic & Prob. \\
\hline C & 3.35 & 1.45 & 2.31 & 0.02 \\
\hline LDP & 0.41 & 0.07 & 6.24 & $0.00^{* * * *}$ \\
\hline LEPS & 0.30 & 0.16 & 1.82 & 0.07 \\
\hline Effect Specification & \multicolumn{5}{|c|}{} \\
\hline R- squared & 0.22 & Adjusted R- squared & 0.21 & \\
\hline F-statistic & 100.43 & Prob(F-statistic) & 0.00 & \\
\hline
\end{tabular}

The results indicate that the dividend per share is significant and the model accounts for $22 \%$ of the variance in the dependent variable. The p-value for earnings per share (0.07) indicates that it is weakly insignificant at $5 \%$ in explaining the changes in the market price per share.

The fixed effect model provides statistically better results than the random effect model, but for both models, the dividend per share is positively related to the market price per share, although the R-squared for the random effect model is low. It should be noted that the market price per share rises as the payout ratio rises. The higher the payout ratio is, the higher the market price per share is. The earnings per share have a negative insignificant relationship with the market price per share. These results confirm that the payment of dividends by a company will positively affect the market price per share, while the earnings per share will have a negative and statistically insignificant relationship with the market price per share. This means that earnings per share do not significantly explain the variation in the market price per share, because shareholders are only concerned with the amount of profit which is paid to them as dividends, whether that amount is paid out of current profit or from a previous year's profit.

In their studies, Nishat and Irfan (2003) and Rashid and Rahman (2009) also found negative insignificant relationships between earnings per share and stock prices. Priya and Azhagaiah (2008) used multiple regression analysis in analysing the impact of dividend payments on shareholders' wealth and found that a higher dividend increases the market value of the share, while a lower dividend decreases the market value of the share. Shareholders seemed to prefer the current dividend to a future dividend and dividend payments were considered to be the most important factor in determining shareholders' wealth.

\section{ESTIMATION OF THE VECTOR ERROR CORRECTION MODEL}

According to the Granger representation theorem, when variables are co-integrated, there must be an error correction model (ECM) that describes the short-run dynamics or adjustment of the co-integrated variables toward their equilibrium values. An ECM consists of a one-period lagged co-integrating equation and the lagged first differences of the endogenous variables. The VECM model is a natural progression from a Vector Auto-regression (VAR) representation, especially when the series levels are non-stationary. Using the VAR, the authors can estimate the ECM. The model used in the current study involves three non-stationary variables; therefore, the ECM would be a simultaneous equation. The presence of co-integration between variables suggested long-term relationships between the variables under consideration; thus, the VECM was applied.

The results of this model appear in Table 12. The upper part of Table 12 presents the estimates of the cointegration equation (estimates of co-integrating relations from the Johansen procedure) and the lower part of table 12 presents the rest of the ECM. In other words, it shows the second step VAR in the differences, including the error correction terms (denoted CoinEq1). The first row in the lower part of Table 12 presents the estimates of the speed of adjustment coefficients for each variable, their standard errors and the t-statistics. The coefficient for dividend per share in the co-integrating vector is 3.760655 .

Below the co-integrating equation, the equation for the change in market price per share is presented in the first column, the dividend per share in the second column, and the earnings per share in the third column. The 
adjustment coefficient for dividend per share is positive and the adjustment coefficient on earnings per share is negative.

The co-integrating equation is given by:

$\operatorname{LMPS}(-1)=86.19192+3.760655 \operatorname{LDP}(-1)-12.40436 \operatorname{LEP}$

The obtained equation shows the direct relationship between the market price per share and dividend per share, and an inverse relation between the market price per share and earnings per share. As all variables are logarithmic, the authors may interpret coefficient in terms of elasticity. The coefficient for dividend per share is 3.76 which proves to be significant, implying that in South Africa, a one percent increase in dividend per share contributes a $3.76 \%$ increase in market price per share. Table 12 contains the results of the VEC model.

Table 12: Vector Error Correction Estimates

\begin{tabular}{|c|c|c|c|}
\hline \multicolumn{4}{|c|}{$\begin{array}{l}\text { Vector Error Correction Estimates } \\
\text { Sample (Adjusted): } 20042010 \\
\text { Included Observations: } 322 \text { After Adjustments } \\
\text { Standard Errors In ( ) \& T-Statistics In [ ] }\end{array}$} \\
\hline \multicolumn{2}{|l|}{ Cointegrating Eq: } & \multicolumn{2}{|c|}{ CointEq1 } \\
\hline \multicolumn{2}{|l|}{ LMPS(-1) } & \multicolumn{2}{|c|}{1.00} \\
\hline \multirow{3}{*}{\multicolumn{2}{|c|}{$\operatorname{LDP}(-1)$}} & \multicolumn{2}{|c|}{-3.76} \\
\hline & & \multicolumn{2}{|c|}{-0.65} \\
\hline & & \multicolumn{2}{|c|}{-5.79} \\
\hline \multicolumn{2}{|l|}{$\operatorname{LEP}(-1)$} & \multicolumn{2}{|c|}{12.40} \\
\hline & & \multicolumn{2}{|c|}{-3.95} \\
\hline & & \multicolumn{2}{|c|}{-3.14} \\
\hline \multicolumn{2}{|l|}{$\mathrm{C}$} & \multicolumn{2}{|c|}{-86.19} \\
\hline & D (LMPS) & D (LDP) & D (LEP) \\
\hline & -0.004685 & 0.043187 & -0.000176 \\
\hline & $(0.00715)$ & $(0.00821)$ & $(0.00312)$ \\
\hline Error Correction & D(LMPS) & D(LDP) & D(LEP) \\
\hline \multirow[t]{3}{*}{ CointEq1 } & -0.00 & 0.04 & -0.00 \\
\hline & -0.01 & -0.01 & -0.00 \\
\hline & -0.66 & -5.26 & -0.056 \\
\hline R-squared & 0.13 & 0.21 & 0.35 \\
\hline Adj. R-squared & 0.05 & 0.14 & 0.29 \\
\hline Sum sq. resids & 61.00 & 80.41 & 11.64 \\
\hline S.E. equation & 0.45 & 0.52 & 0.20 \\
\hline F-statistic & 1.70 & 3.08 & 6.37 \\
\hline Log likelihood & -189.05 & -233.52 & 77.68 \\
\hline Akaike AIC & 1.34 & 1.61 & -0.32 \\
\hline Schwarz SC & 1.64 & 1.92 & -0.02 \\
\hline Mean dependent & 0.14 & 0.07 & 0.01 \\
\hline S.D. dependent & 0.47 & 0.56 & 0.24 \\
\hline \multicolumn{2}{|l|}{ Determinant Resid Covariance (Dof Adj.) } & 0.00 & \\
\hline \multicolumn{2}{|l|}{ Determinant Resid Covariance } & 0.00 & \\
\hline Log Likelihood & & -314.09 & \\
\hline Akaike Information Criterion & & 2.45 & \\
\hline Schwarz Criterion & & 3.40 & \\
\hline
\end{tabular}


The lower part of Table 12 shows the speed adjustment coefficients, which reveals that only one variable is adjusting. The adjustment coefficient on co-integrating equation 1 for the dividend per share is positive. The adjustment coefficient for earnings per share is showing negative.

The results from the vector error correction estimates confirm the previous results obtained. The results suggest that there is a long-run relationship between the dividend per share and the market price per share. The overall results of this study indicate that dividend payments have a significant positive effect on the market price per share. It is clear that is one of the most important decisions for managers and investors. It should be noted that there are many internal and external factors which simultaneously affect the market price per share, and it is almost impossible to segregate the effects. As a result, variations remain. The VECM results point to the fact that one variable will adjust to the long-run trends. It needs to be noted that the statistical tests were performed using Eviews 7.

\section{CONCLUSIONS}

This research was undertaken to determine the relationship between dividend payments and stock prices by examining a sample of 46 paying companies listed on the Johannesburg Securities Exchange for the period 1995 to 2010. In respect of the dividend relevance theory, based on the panel data analysis, using fixed and random effect models, a positive relationship was found between dividend payments and shareholders' wealth. The three variables (dividend per share, earnings per share, and market price per share) were at first non-stationary.

In the unit root test of levels, an intercept were included and also a time trend if the data was trended. In the unit root of the first differences, only the intercept without the time trend was included. As a result, in levels using the market price per share, dividend per share, and earnings per share, the probability of results suggested that the three variables are not stationary. Logarithms were introduced to see whether there might be a change, but still the variables were non-stationary. As a result, the three variables were not co-integrated; this means that they were not integrated of the same order. Consequently, they had to be differenced. After being differenced, the MPS, DP and EP became stationary of order I (1). The model defined a long-run equilibrium relationship between the cointegrated variables. Therefore, a co-integration test was conducted. The Johansen co-integration test suggested one co-integrating equation.

Fixed and random effect models of regression analysis were applied to the panel data. The fixed effect method was used to control all the stable characteristics of the companies included in the study over a fixed period of time. Compared to the random effect method, the fixed effect method provided statistically better results by removing the bias from the data and explaining only within-sample variations. It was expected that the dividends and earnings per share would be positively associated with the market price per share and that they would share a long-run relationship. The results of the study indicate that the dividend yield is positively related to the market price per share in both the fixed and random effect models, as the models significantly explain the variations in the market price per share.

This further indicates that investors want dividends, as they provide signals about the future prospects of the company. The earnings per share do not have a significant impact on the market price per share. These results confirm that the payment of dividends will positively affect the market price per share while the earnings per share will not.

\section{AUTHOR INFORMATION}

Professor Johannes de Wet received the degrees BAccountancy (Hons) and MBA from the University of Stellenbosch and has a chartered accountant, CA(SA) qualification. He also obtained a DCom (Financial Management) degree from the University of Pretoria. Professor De Wet lectured at the University of Stellenbosch for 15 years and at the University of Pretoria for 12 years. He has presented numerous courses in Financial Management and Management Accounting. He has also published articles in academic journals and made presentations at conferences. E-mail: johannes.dewet@up.ac.za (Corresponding author) 
Mvita Mpinda studied in the Democratic Republic of Congo (DRC) at the undergraduate level and obtained his Masters (Financial Management) at the University of Pretoria in 2012. He started his studies in order to obtain a Ph.D. under the supervision of Professor Johannes de Wet. E-mail: mvitampinda@gmail.com

\section{REFERENCES}

1. Auret, C.J., \& De Villiers, J.U. (2000). A comparison of earning per share and dividend per share as an explanatory variable for share prices. Journal of Studies in Economics and Econometrics, 24: 39-53.

2. Botha, D. (1985). The effect of dividend policy on changes in shareholders' wealth. Unpublished Masters' Dissertation. University of Port Elizabeth.

3. Botha, D., Bosch, J.K. \& Van Zyl, G.J.J. (1987). The effect of dividend policy on changes in shareholders' wealth. The South African Journal of Economics, 55(2): 101-113.

4. Brigham, E.F. \& Gordon, M.J. (1968). Leverage, dividend policy, and the cost of capital. Journal of Finance, 23: 85-103.

5. $\quad$ Correia, C., Flynn, D., Uliana, E. \& Wormald, M. (2006). Financial management. $6^{\text {th }}$ ed. South Africa: Juta.

6. Clarke, S. (2007). The future earning information content of dividend changes and share repurchase program on the JSE. Unpublished MBA research report, Graduate school of business, University of Cape Town.

7. Du Plessis, D.P., Archer, A.A. \& Affleck Graves, J.F. (1986). Historic income versus inflation adjusted income in the dividend decision. South African Journal of Business Management, 17(3): 119-124.

8. Fisher, G.R. (1961). Some factors influencing share prices. Economic Journal, 71: 121-141.

9. Gordon, M.J. (1959). Dividends, earnings, and stock prices. Review of Economics and Statistics, 41: 99105.

10. Ghosh, A., Coyne, C., \& Boldin, R. (2004). Corporate dividends and earnings. Is there a long-run relationship? Delhi business review, 5(1), January-June 2004.

11. Goodstein, L., Nolan, T. \& Pfeiffer, J .W. (1993). Applied strategic planning: how to develop a plan that really works. USA: McGraw-Hill.

12. Gevers, W.R. \& Hamman, W.D. (1988). Dividend policy in the period of continuing inflation: an empirical study of listed industrial companies, 1982-1986. Studies in Economics and Econometrics, 12(2): 15-23.

13. Granger, C.W.J. \& Newbold, P. (1974). Spurious regression in econometrics. Journal of Econometrics, 2: 111-120.

14. Hussainey, K., Mgbame, C.O. \& Chijoke-Mgbame, A.M. (2011). Dividend policy and share price volatility: UK Evidence. Journal of Risk Finance, 12(1): 57-68.

15. Kenyon, F. \& Mathur, S.S. (2001). Creating value: successful business strategies. $2^{\text {nd }}$ ed. Great Britain: Paperback.

16. Khan, K.I., Aamir, M., Qayyum, A., Nasir, A. \& Khan, M.I. (2011). Can dividend decision affect the stock prices: a case of dividend paying companies of KSE. International Research Journal of Finance and Economics (76) 67-74.

17. Knight, R.F. \& Affleck-Graves, J.F. (1987). An evaluation of dividend signalling on the Johannesburg Stock Exchange. South African Journal of Business Management, 18(2): 79-82.

18. Lease, R.C., John, K., Kalay, A., Loewenstein, U. \& Sarig, O.H. (2000). Dividend policy: its impact on the firm value. Boston: Harvard Business School Press.

19. Leedy, P.D. \& Ormorod, J.E. (2005). Practical research planning and design. $8^{\text {th }}$ Ed. Upper saddle Rivers, NJ: Pearson.

20. Lintner, J. (1956). Distribution of incomes of corporations among dividends, retained earnings and taxes. Journal of the American Economic Review, 46(2): 97-113.

21. Maditinos, D.I., Sevic, Z., Theriou, G.N. \& Tsinani, V.A. (2007). Individual investors' perceptions towards dividends: the case of Greece. International Journal of Monetary Economics and Finance, 1(1): 18-31.

22. Maytham, A., Gilbert, E. \& Firer, C. 2008. Dividend policy in South Africa. The Investment Analyst Journal, 68: 5-19.

23. Miller, M. \& Modigliani, F. (1961). Dividend policy, growth and the valuation of shares. Journal of Business, (34) 411-433. 
24. Nazir, M.S., Nawaz, M.M., Anwar, W. \& Ahmed, F. (2010). Determinant of stock price in Karachi Stock Exchange: the mediating role of corporate dividend policy. International Research Journal of Finance and Economics, (55) 100-107.

25. Nishat, M. \& Irfan, C.M. (2003). Dividend policy and stock price volatility in Pakistan. $11^{\text {th }}$ Pacific Basin Finance, Economics and Accounting Conference.

26. Ooms, L.L., Archer, A.A. \& Smit, E. vd M. (1987). The informational content of dividend on the Johannesburg stock exchange: an empirical analysis. South African Journal of Business Management, (18) 187-197.

27. Pandey, I.M. (2002). Financial management. New Delhi: Vikas.

28. Pani, U. (2008). Dividend policy and stock price behavior in Indian corporate sector: a panel data approach. Indian institute of technology. [Online] Available from: http://ssrn.com/abstract=1216171 [Accessed: 2012-05-10].

29. Priya, S. \& Azhagaiah, R. (2008). The Impact of dividend policy on shareholders' wealth. International Research journal of Finance and Economics, Issue 20: 181-187.

30. Rappaport, A. (1998). Creating shareholders value: a guide for managers and investors. New York: The Free Press.

31. Rashid, A. \& Rahman, A.Z. (2009). Dividend policy and stock price volatility: evidence from Bangladesh. Journal of Applied Business Economics, 8(4): 71-81.

32. Rowe, GW. (2001). Creating wealth in organization: the role of strategic leadership. Academy of Management Review, 83(4): 14-18.

33. Sutton, J.C. (1983). Does strategy pay? Managerial and Decision Economics, 4(3): 153-159.

34. Tibrewala, R., Biger, N. \& Gill, A. (2010). Determinant of dividend payout ratios: evidence from the United States. The Open Business Journal, 3: 8-14.

35. Varaiya, N., Kerin, R. \& Weeks, R. (1987). The relationship between growth, profitability and company value. Strategic Management Journal, 8(5): 487-497.

36. Walter, J.E. (1963). Dividend policy: its influence on the value of the enterprise, Journal of finance, 18 : 280-291. 
NOTES 